\title{
DANTE ALIGHIERI E A VOZ FEMININA SOBREDETERMINADA: AGONISMO E FANTASMAGORIA
}

\author{
Pedro Carlos Louzada Fonseca \\ Universidade Federal de Goiás (Brasil) \\ pfonseca@globo.com \\ Norival Bottos Júnior \\ Universidade Federal de Goiás (Brasil) \\ nonobottos@gmail.com
}

Recebido: 15/01/2019 - Aprovado: 24/06/2019

DOI: doi.org/10.17533/udea.lyl.n76a09

\begin{abstract}
Resumo: A mulher é tema central para Dante, desde seus primeiros poemas líricos até a Comédia. Nessa perspectiva temática, através do método comparativo e da análise crítico-teórica, este artigo examina a maneira pela qual o poeta se utiliza da operação fantasmática do amor cortês para anular a voz feminina em Beatriz de Vida nova e, posteriormente, como a dama florentina ressurge na Comédia dotada de voz masculina do próprio Dante em constante processo de autoescuta. Nesse aspecto mimético, o artigo pretende concluir pela observação de que a poética de Dante apresenta traços de emancipação da estética medieval em direção ao moderno.
\end{abstract}

Palavras-chave: voz feminina; sobredeterminação; fantasma; agonismo; Dante Alighieri.

\section{DANTE ALIGHIERI AND THE OVERDETERMINATED FEMALE VOICE: AGONISM AND PHANTASMAGORIA}

\begin{abstract}
Women are the central theme for Dante, from his first lyric poems to the Comedy. In this thematic perspective, through a comparative method and critical-theoretical analysis, this article examines the way in which the poet used the phantasmatic operation of courtly love to annul the female voice of Beatrice in The New Life and how later on the Florentine lady resurfaced in the Comedy endowed with the masculine voice of the own Dante in constant process of self-listening. In this mimetic aspect, the article intends to conclude that Dante's poetics presents traces of emancipation from medieval aesthetics towards the modern.
\end{abstract}

Key words: female voice; overdetermination; phantasm; agonism; Dante Alighieri.

LINGÜÍSTICA Y LITERATURA 


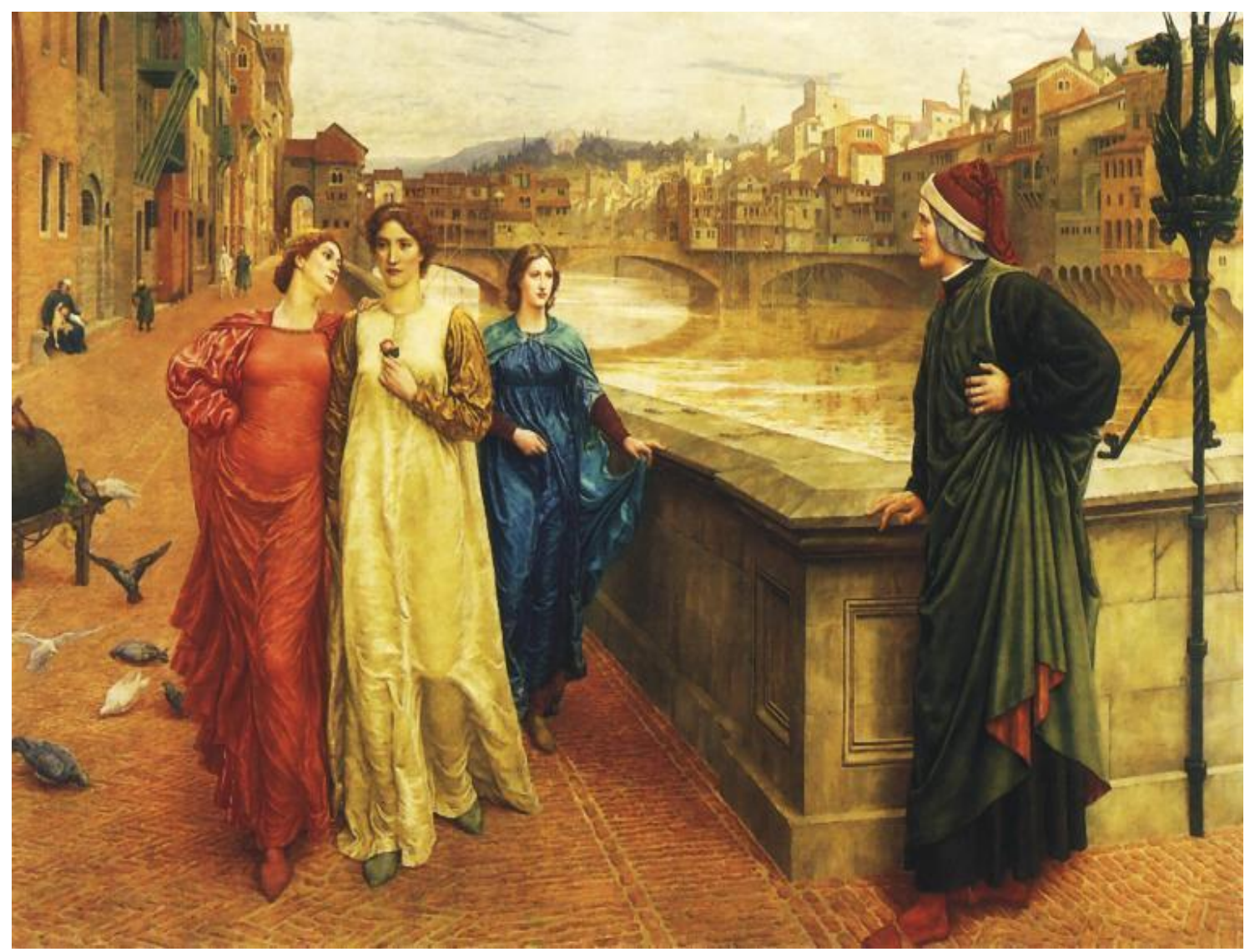

Figura 1. Dante e Beatrice (1882/1884). Henry Holiday, l'incontro immaginario fra Dante e Beatrice (con il vestito bianco) accompagnata dall'amica Vanna (con il vestito rosso), sul Ponte Santa Trinità in Firenze

\section{Introdução}

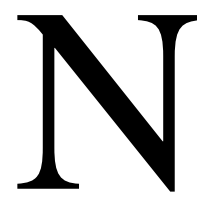

a variante teológica do amor cortês chamada doce estilo novo, Dante Alighieri pode reunir seus diversos poemas sobre a jovem musa chamada Beatriz Portinari (Bice) num livro chamado Vida nova. Nele, o poeta se dedica a estabelecer um diálogo entre o conteúdo dos poemas e as análises e comentários que se seguem após cada poema. São comentários do próprio Dante e de outros poetas que leram seus sonetos e que também foram influenciados pelas cantigas trovadorescas que floresceram na região da Provença, na França, cerca de dois séculos antes de Dante. Segundo Eduardo Sterzi: 
A civilização feudal - a civilização dos castelos e dos cavaleiros - havia encontrado sua mais plena e fecunda expressão poética no fenômeno do trovadorismo. Expressão plena porque, na lírica dos trovadores, as ritualizações mais próprias do mundo feudal aparecem concentradas na figuração de uma voz que canta seu amor por uma dama quase sempre inalcançável, ou, quando alcançada, ainda inapreensível, insustentável; nesta relação mínima entre um sujeito amoroso e seu objeto, transposição para o âmbito da relação submissa entre vassalo e senhor, toda uma sociedade se dá a ver, [...] com suas hierarquias sociais, suas estritas regras de conduta e de discurso, seu jogo constante entre liberdade e interdição (2008, p. 61-62).

É importante notar que a produção poética de Dante se situa entre dois períodos, pois, se na Vida nova é o cotidiano feudal que o poeta florentino se preocupa em retratar em poemas e canções trovadorescas, o mesmo não se pode dizer de sua última e mais importante obra A divina comédia. Quando comparadas as duas obras, tornam-se perceptível as várias características que as separam. Uma das importantes características temáticas dessa separação consiste exatamente em situar o papel da mulher, que passa de figuração do amor idealizado em Vida nova para a sublimação desse sentimento como realização da obra como potência na Comédia, ou seja, a realização do poeta num plano muito mais próximo da centralidade estética e canônica, da supremacia do gênio poético de Dante que ultrapassa qualquer identificação teológica do amor cortês medieval. O que se vê na Comédia é a realização suprema do poeta Dante, ponto de vista defendido por Harold Bloom, quando diz:

Nada destrói o gênio de Dante mais prontamente do que comentários que lhe exaltam a suposta devoção religiosa e as virtudes humanas. Poeta algum, nem mesmo John Milton, foi um poço de orgulho assim como foi Dante. Não podemos confiar na atitude de Dante, com relação a Brunetto Latini, seu «mestre», situado no Inferno devido a uma sodomia talvez inventada pelo próprio Dante. Estácio, poeta romano medíocre, que, decerto, se manteve pagão, surge na Comédia como grande poeta, secretamente, cristão. Não sendo, na verdade, um mártir, é possível que o Estácio de Dante seja uma insinuação ao próprio poeta florentino, cujo gênio era para ele mais importante do que as santidades de Agostinho e Aquino (2001, p. 122).

Nesse momento da Comédia, Dante já não canta mais a vassalagem ao seu senhor, pois abandona a doutrina estética dos Fiéis do amor, punindo seu melhor amigo Guido Cavalcanti no Canto $\mathrm{X}$ do Inferno. Na Comédia, Beatriz ressurge e pode enfim falar, mas o modo como Dante pode manter seu agonismo extremo se deixa ver pela via do apelo à musa com representação figurativa da Virgem. Esse apelo só se torna possível graças ao modo como Dante sofisticou o pensamento misógino, cuja origem remonta a uma tradição 
firme e disseminada com muita autoridade desde Aristóteles até a literatura patrística e seu legado medieval.

Não permitir que à mulher falar além do devido e discreto é um dos topoi mais glosados da cultura misógina da Idade Média. Entretanto, apenas no século XII, a Igreja começa a tolerar e até mesmo a perceber a relevância da figura da mulher para a organização da vida social. É nessa altura que as mulheres tornam-se recebidas na Igreja e ouvidas pelos padres; os conventos se multiplicam, como é o caso de Fontevraut; as mulheres da nobreza passam a ter direito à herança, mesmo que continue havendo discrepância entre a prescrição legal e a prática social e, o que é mais importante, a figura da Virgem serve como modelo da dama cortês. Portanto, surge a figura da mulher como objeto de culto. Nesse contexto, o discurso do amor cortês opera de um modo peculiar, de redução da mulher à condição de uma categoria. De acordo com Howard Bloch:

A dama cortês enquanto um avatar da Mãe de Cristo certamente não é nada de novo. Estudiosos desde o século XIX têm visto na cortesania uma manifestação secular da mariologia medieval, chamando a atenção para a nostalgia do enamorado por um ideal distante, [...] a tentativa de espiritualizar a materialidade do corpo conforme as linhas do misticismo cisterciense, a glorificação do sofrimento, o êxtase do enamorado, a mulher como fonte de redenção, e a infusão em termos religiosos na esfera semântica do amor cortês (1995, p. 218).

Bloch, ao contrário de Júlia Kristeva, que posiciona a mãe como componente biológico que se manifesta nas várias formas culturais em que a figura da Virgem aparece, vê nessa relação entre a musa e a Virgem um componente ideológico de correntes culturais determinado por necessidades materiais. Ou seja, a fonte de adoração da mulher estaria mais ligada ao papel cada vez mais relevante da figura da mulher na sociedade, bastante diferente, por exemplo, do que se percebe nos séculos anteriores onde as mulheres não tinham acesso a herança paterna.

As mulheres da baixa nobreza se tornam modelos de adoração enquanto ideal por razões muitas vezes ideológicas, o que pode ser percebido, de acordo com Bloch, no modo como se associam exemplos de escritos religiosos que buscaram trazer a mulher para a vida religiosa, como procede Burchand de Worms. Autor de Liber decem capitulorum [Livro de dez capítulos], ele apresenta um pavoroso perfil da mulher, num estudo bastante austero a respeito da figura da mulher. 
Dentro desse espaço austero de vida reside um dos fatores que fazem com que a Beatriz que fala na Vida nova ou na Comédia não seja, de modo algum, uma jovem florentina que ele encontrou apenas duas vezes. $\mathrm{O}$ que se ouve pela boca de Beatriz, mesmo quando alçada ao mais alto dos círculos do Paraíso, não é senão a própria voz do poeta encarnado na figura de sua musa. E essa inversão permite a Dante encontrar no ato de cantar em nome de sua musa seu verdadeiro tom poético.

Na Vida nova, esse primeiro e quase inclassificável livro de Dante, não se percebe algo que se assemelhe à expressão moral própria à figura de uma jovem florentina da época, ou seja, no que diz respeito à mulher amada e cantada ao longo de mais de cinquenta poemas de amor fica-se ao relento, pois ela nada pode dizer e nem o próprio Dante nada pode saber sobre ela. A dama de Dante Alighieri tem, em comum com as damas do amor cortês, a propriedade de não falar, de não dar acesso ao que pensam, de não existir. São, desse modo, pinturas idealizadas do Amor e encarnadas em jovens como Beatriz. Há uma série de ambiguidades e contrastes na representação da mulher em Dante, especialmente na passagem do gênero lírico para o épico. Entre a Beatriz de Vida nova e a Beatriz que ressurge na Comédia, podem ser encontradas mais que duas representações diferentes de uma mesma personagem. A Beatriz da Comédia em nada se assemelha à representação medieval da mulher herdada pela tradição da patrística. Ela se mostra extremamente loquaz; é verdadeiramente uma Beatrix Loquax (felicidade beata e loquaz).

Essa verdadeira reconfiguração da dama trovadoresca; essa beata e ao mesmo tempo loquaz persona parece contradizer toda a representação misógina dos Padres da Igreja, porque pode ser vista a atuar uma figura híbrida, ou no limiar entre a voz masculina e a imagem feminina, ou até mesmo mais masculina do que feminina. Por outro lado, Beatriz ainda conserva traços do erotismo típico das damas de amor cortês; sua existência poética é sem igual na história da literatura. Apesar de híbrida, dama com voz masculina, a Beatriz que ressurge na Comédia não deixa de centralizar todas as suas ações e fala em torno de Dante como poeta supremo.

A Vida nova pode ser compreendida como o início de um longo processo em busca da vitalidade poética. Não seria mesmo exagero afirmar que este talvez fosse o projeto central para o poeta florentino, que resultou num dos poemas épicos mais importantes da literatura 
ocidental, sua obra definitiva, A Comédia. Mas a Vida nova apresenta ainda um poeta muito pouco à vontade com os dilemas estético-filosóficos de sua época. Há muito de novo nesse texto de juventude: metapoesia, autobiografia, novas possibilidades métricas para o soneto e crítica literária inovadora, com princípios bem diferentes canonizados por Aristóteles, Platão ou Longino. Vida nova é permeada, de forma irônica e talvez mesmo inconscientemente, pelo pensamento epicurista de Lucrécio via Virgílio, disposição filosófica que encontra seu ápice na Comédia, quando os ecos Lucrécio ecoam em Virgílio de modo mais intenso.

A necessidade de seguir os padrões adotados pela tradição grega clássica talvez tenha sido um conflito bastante difícil de o poeta interagir, se for considerado que para Virgílio, o Mestre de Dante, os nomes de Lucrécio e Epicuro representavam bem mais do que Homero, e o nome de Virgílio haveria de, até o último capítulo do Purgatório, desaparecer por completo do campo de influência de Dante Alighieri. É certo que Dante não havia lido Lucrécio, detalhe histórico importante para se considerar as motivações poéticas da escolha de Virgílio como seu precursor adequado e também seu guia nas duas primeiras partes de $A$ divina comédia. Este é um fato deveras curioso, pois a leitura de Lucrécio teria horrorizado Dante, mas nada esclareceria acerca da figura mais importante no conjunto da obra de Dante Alighieri, o leitmotiv encarnado na figura da bela jovem Beatriz Portinari, de quem nada mais se sabe além do fato de ser filha de um banqueiro e de ter falecido cerca de um ano após seu casamento com outro banqueiro, aos vinte e um anos de idade.

Entretanto, devem ser compreendidas as razões pelas quais Dante Alighieri escolheu o fantasma de Beatriz, que surge nos sonetos como o caminho para a verdade suprema do amor, para na Comédia ressurgir como a própria voz do poeta, ou seja, como uma voz masculina que constitui a única possibilidade de representação da Verdade. Ambos os termos da verdade, se se deixar de lado as abordagens teológicas, dão a pensar a figura da jovem florentina como o caminho que leva à verdade da obra de arte em Dante. Pode-se mesmo sugerir que esse seja provavelmente, senão o único, talvez o maior objetivo de Dante como poeta, inicialmente lírico, depois épico. Por outras palavras, trata-se de um poeta pioneiramente dotado de forte noção de individualidade, porque nenhum outro até 
então tinha sido tão consciente da importância do fortalecimento do Ego para a criação da obra de arte.

É no contexto dessas reflexões acerca do despontar dessa comentada dimensão moderna do «eu» dantesco através da figura de Beatriz que, apesar de ser assunto suficiente para um crítico-teórico ulterior, que ainda uma apreciação complementar merece ser feita sobre a contextualização do marco da poesia moderna italiana do século XIV, contrastando, por exemplo, o que ocorre com Petrarca e Laura, e a maneira como se instala a condição do sujeito poético ocidental como sujeito amoroso e, desse modo, o papel da musa cuja existência própria não importa, senão apenas a sua imprescindível participação na realização do poeta enquanto tal.

\section{O sorriso gentilíssimo e fantasmático de Beatriz}

Para Dante, a escolha do caminho não deve se situar entre o divino e o mortal, mas ao contrário, deve uni-los como partes integrantes do todo. Essa concepção é base do pensamento do doce estilo novo, uma espécie de doutrina estética dos Fiéis do Amor, seita secreta a qual Dante deve ter pertencido durante algum tempo. Quando exatamente Dante teve consciência de que deveria fazer de Beatriz sua musa é algo bastante difícil de definirse, mas deve ter tido início, provavelmente, poucos anos após a morte de Beatriz. A lembrança da jovem que lhe acena com um sorriso — que demarcará, ironicamente, o fim do amor cortês e o início de uma percepção estética muito mais aguda do que sua época seria capaz de assimilar - é a base do amadurecimento de Dante enquanto poeta.

Está-se aqui bem próximo do que Giorgio Agamben (2013), em O homem sem conteúdo, propõe como terror divino, que pode ser entendido como a potência estética diante da beleza da palavra poética. E são os leitores de Dante que caem de joelhos diante de Beatriz. E, ao longo da história da progressiva racionalidade do mundo, é dessa mesma potência criativa que se esquece pouco a pouco, que emerge o poder terrível da arte que prostra o homem, o assimila completamente ou o deixa sozinho à sombra de certo tipo de estranhamento que só a arte permite experimentar. 
Para pensadores que seguem na esteira de Friedrich Nietzsche (2015, p. 221), é preciso superar de algum modo a estética kantiana do belo como fruição desinteressada. A arte não pode estar envolta num ar benévolo, pois estar completamente inocente diante dos perigos que a entregam à palavra poética pode implicar naquilo que deveria ser sua essência mesma, o perder-se de si mesmo na palavra do outro, ou seja, a alteridade seria o grande trunfo da arte, pois o «eu» só se reconheceria a partir da experiência do contato com o «outro», do autor do mundo que não é o nosso, mas sim, o desvelamento, não da arte pela arte, mas da arte como sentença da verdade das coisas em si mesmas, noção encontrada na Comédia de Dante, e também esboçada nas obras anteriores. Segundo Agamben (2012, p. 16), «[...] o que está em jogo não parece que seja, de modo algum, a produção de uma bela obra de arte, senão a vida ou a morte do autor, ou, no mínimo, a saúde do autor ».

O que parece estar em jogo então é a figura de Beatriz como fantasma (fantasia) para a verdade da arte em Dante, ou seja, Dante se apresentando como a verdade tendo como caminho seu Cristo interior, Beatriz. Jorge Luis Borges (1999, p.418) costumava dizer que para Beatriz, Dante não significava nada, ou quase nada, mas para o poeta Dante, a jovem Beatriz significa tudo. Ao longo da busca pela Verdade (obra de arte) é o visível do invisível, ou seja, o fantasma de Beatriz que fará com que o poeta seja capaz de ver todos os elementos, traços e atos capazes de levá-lo à verdade, a alcançar, na Comédia, já em seus últimos anos de vida, uma nova forma de produzir não apenas a obra de arte, mas o próprio modo de se pensar a obra de arte.

Com o ostracismo crescente da figura do trovador surge a figura do compositor, e no vácuo entre ambos surge outra figura, a do poeta moderno, e dentre eles, o mais notável nesse período é o poeta florentino Dante Alighieri, principalmente por carregar suas obras com um vitalismo tão intenso que poucas vezes se viu desafiado à altura, mesmo nos séculos seguintes. Sendo assim, seria este o momento em que se opera, pela primeira vez, uma mudança drástica na relação representacional do sujeito, do objeto e da imagem; mudança que é notada no contraste entre as duas obras de Dante Alighieri acima mencionadas. Está-se diante da passagem da imagem da Virgem para a de Eva:

O amor era visto como pulsão egoísta, um apetite: é por mim, para saciar minha cobiça que me lanço sobre tal objeto, sobre tal ser. Como Eva quando, escutando a serpente, estendeu para o 
fruto. No começo do século XII, nas escolas parisienses, desenha-se uma reviravolta. O amor, o bom amor, não é mais visto como uma captura, mas como um dom. [...] Em um primeiro momento, o homem estima a si próprio. $\mathrm{O}$ apetite tem necessariamente sua origem no mais profundo do carnal. Somos carne. Deus se fez carne e a reabilitou. Ela constitui o fundo sobre o qual toda a espiritualidade se erige. Depois, subindo um degrau, o homem chega a amar Deus. [...] Entre amigos, na paridade, toda hierarquia apaga-se (Duby, 2001, pp.124-125).

A lírica medieval e a figura do trovador sucumbem ao mesmo tempo em que surge a lírica moderna e a figura do poeta, mas esta transição é demarcada por um conflito difícil de explicitar, por se tratar de um espaço de hesitação e de perplexidade pelo surgimento de um lançar-se em direção ao objeto fantasmático que se instaura a partir do espaço privilegiado erigido entre as ruínas da prática medieval de cortesia - a emoção pura, despersonalizada - e o trabalho intelectual, dotado de outros valores, de domínio mais aguçado da linguagem figurativa e maior criatividade, critérios que a lírica medieval não conhecia. Surge então este espaço onde a emoção deve passar pela ordenação de um modo de pensar muito mais rigoroso, onde o corpo, o objeto de desejo precisa desaparecer para que emirja o que está visível na invisibilidade da obra, inclusive o nome do autor, a verdadeira autoridade por trás da obra.

A Era Moderna gira em torno da construção da subjetividade e da identidade; do fortalecimento do sujeito pela linguagem escrita, tanto quanto a exploração do medo da morte, e é justamente neste espaço intervalar que o corpo da mulher se torna motivo de desejo tanto carnal quanto espiritual, «Eva estende sua mão para o fruto» (Duby, 2001, p. 125), assim, a cortesia medieval desaparece deixando poucos rastros de uma psicologia própria numa sociedade em transição e cuja ética social e culturalmente começa a findar.

\section{A pneumatologia dos espíritos sutis, de cuja essência lembrar suscita o horror}

As primeiras tentativas de Dante Alighieri em relação à poesia já se mostram inteiramente veiculadas no doce estilo novo, uma espécie de seita secreta de poetas líricos. O que Giorgio Agamben busca enfatizar em Estâncias (2012) é o fato de que o que está em jogo na relação de Dante e os outros poetas dessa seita secreta é que a doutrina pneumática não apenas influencia, mas dita o modo como esses poetas lidam com o contexto histórico da época, com as concepções soteriológicas e filosóficas, a cosmologia. Enfim, trata-se de 
uma prática poética bastante diferente das canções de amor dos trovadores. Mesmo em seus primeiros poemas dedicados à dama secreta, a teoria pneumática já surge e reflete as características fundamentais da tradição neoplatônica e médicas. Tome-se como exemplo um dos primeiros poemas de Vida nova, «Nos olhos leva a minha dama»:

Nos olhos leva a minha dama o Amor, e por isto belo torna quanto vê; por onde passa se desloca tudo a vê-la, e o peito faz vibrar a quem saúda.

Tanto, que baixando logo o rosto, esvanecido, de todo o seu defeito, então, suspira: diante dela fogem soberba e ira. Ajudai-me, damas, a honrá-la. Toda a doçura, todo o pensar humilde, no peito, nasce de quem falar a ouve.

- Louvado seja quem a viu primeiro.

O que parece, se sorri um pouco, não se pode dizer, ou ter em mente, tanto é novo e gentil milagre.

(1993, p. 45).

O mecanismo pneumático do amor está presente em cada um dos versos desse poema. Os três movimentos que constituem a natureza formal do soneto clássico, tese, antítese e síntese acompanham também o triplo movimento do mecanismo pneumático: inicialmente o espírito de percepção é o olhar, presente nas duas primeiras estrofes. Esse olhar deve ser capaz de transcender o objeto de amor para que o espírito da mente possa dele se apossar em toda sua plenitude, como se nota nos dois últimos tercetos. O movimento é contínuo, pois, em seguida, o poder cognitivo do poeta faz com que o espírito seguinte, o corpo, também seja arrebatado, fazendo estremecer todo o ser do poeta, como afirma o próprio Dante nos comentários do mesmo poema, deixando claro que, além do jogo de sedução, há preponderantemente um jogo de espelhos entre sentimento e razão, ausência e presença, fato e fantasia:

Desde aquela visão passou o meu espírito natural a ser contrariado na sua atividade, pois que a alma seguia toda entregue a pensar naquela gentilíssima mulher. Pelo que em pouco tempo me tornei de tão fraca e débil condição que muitos amigos se afligiam com o meu aspecto, e muitos outros, cheios de inveja, desejavam saber de mim aquilo que de todo eu queria ocultar a outrem. $\mathrm{E} \mathrm{eu}$, protegido das suas maliciosas perguntas pela vontade do Amor, o qual me dirigia conforme o conselho da razão, respondia-lhes que era o Amor quem me havia reduzido a tal 
estado. Dizia o Amor, porque trazia no rosto tantos dos seus sinais que o não podia dissimular. E quando me perguntavam: «Por quem te destruiu assim o Amor?», olhava-os sorrindo, e nada lhes dizia (1993, pp. 12-13).

O fantasma da dama gentilíssima é o verdadeiro objeto de amor. Nele reside o desejo fantasmático e a imaginação pode prescindir do objeto, porque agora é o simulacro que interessa ao poeta. Por isso Dante Alighieri sorri aos amigos e nada responde. Embora à custa de permanecer preso ao significado alegórico, Dante promove uma forte desleitura do amor cortês ao expressar com todo esplendor o advento da dama gentilíssima como ressurgimento do espírito que se vê na ausência do objeto de desejo. Pode-se pensar em Beatriz recriminando Dante, no Paraíso, quando o poeta não consegue desviar os olhos de sua amada, enquanto a sua frente é a própria figura de Jesus Cristo que o adverte dos perigos de um caminho desregrado. Mas não se pode pensar na mesma figura sem a psicologia fantasmática que lhe surge de modo sutil, porque, essencialmente nesses sonetos tem-se a sensação de que não há um rosto para se contemplar, não há sequer a garantia de que há de fato uma bela dama, embora nessa ausência, o poeta faça ver o objeto de felicidade plena como imagem. Esse é um detalhe extremamente importante, pois não havia nada semelhante na lírica medieval, voltada para a presença em si do objeto de desejo, algo que Agamben observa cuidadosamente em Estâncias, que viam no doce estilo novo mero reflexo de circunstâncias sociais.

Subjetividade como forma de negação do corpo. Na lírica medieval, o acento pesava sob o lugar do corpo, lugar onde a alma não está. A circunscrição da alma é o «locus...Qui non est locus», segundo Agamben (2012). No poema moderno, o processo de escrita subverte a lógica medieval; o objeto desejante é o lugar de onde não se está, por isso a subjetividade se impõe, negando o corpo em nome da plenitude da transcendência. Na Vida nova, Dante inaugura a coincidência entre a vida e a poesia, entre texto e experiência. $\mathrm{O}$ resultado é a impossibilidade de se verificar os vínculos entre versos e fatos, o que surge é uma poesia que tem como característica principal o modo como os poemas serão recebidos, em que não se tem mais a presença corporal do recitador, ou o trovador, ou mesmo um interprete a validar o poema. O poeta se torna também ele um fantasma, como no caso do poema seguinte, escrito após um sonho, como descreve o próprio Dante acerca do poema endereçado à Guido Cavalcanti, membro dos Fiéis do Amor:

LINGÜÍSTICA Y LITERATURA 
A toda a alma prisioneira, a todo o coração gentil, até aos quais correndo vá o meu lamento (e que diga cada um aquilo que sente) saúde em seu Senhor, ou seja o Amor. Quase se tinha atingido a hora em que a luz estelar mais viva nos parece, quando de súbito o Amor se me mostrou, e de tal forma que lembrá-lo me horroriza.

Alegre me parecia, tendo numa das mãos meu coração, e nos braços, envolta num cendal, minha dama, adormecida.

Despertou-a; e desse coração, que ardia, ela comia, receosa, humildemente.

Vi-o depois afastar-se soluçando (1993, p. 11).

Dante escreve sobre o sonho que antecedeu o poema acima. Diante do espírito de um anjo envolto em luz que surge diante dele na terceira hora da noite (vinte e uma horas da noite), o jovem poeta fica tão surpreso no momento em que vê nos braços do anjo sua «dama gentilíssima» que humildemente comia o coração do poeta. Os versos sugerem que ela comia seu coração enquanto recuava diante dele. John Stuart Mill dizia que a poesia é ouvida por acaso, e não ouvida intencionalmente, seria esse o mesmo caso dos sonhos que dão acesso às imagens que os poetas recriam?

Segundo Agamben (2012), a poesia, em Vida nova, exibe um caráter mais próximo das práticas hermenêuticas da psicologia patrística da época do que se pensava antes. Tais práticas não só lhe são paralelas, mas muitas vezes estão incorporadas ao texto primário, borrando a própria distinção entre textos primários e secundários. Essa não é uma linguagem pela qual o objeto fala de algo, mas antes uma linguagem pela qual o conteúdo fala a partir de dentro do objeto, diferente da lírica medieval.

Os versos no poema moderno repensam o espaço recriado através das imagens poéticas que se erguem das ordenações imagéticas construídas numa ordenação tangível, para só então encontrar seu lugar adequado. Essa zona de contato, esse espaço amoroso, presente na lírica medieval onde o conteúdo encontra e possui seu objeto pelo ato performático, é uma linguagem diferente da linguagem da poesia lírica moderna, pois na lírica medieval a linguagem conta com uma interioridade reforçada pelo isolamento e pela proteção contra o fora da linguagem. Esse espaço fantasmático tem caracterizado, em outros termos, a 
diferenciação entre a canção lírica medieval e a poesia lírica ao longo da história. O agente e o objeto da linguagem na poesia têm mudado constantemente ao longo da história literária.

$\mathrm{O}$ autoconhecimento da linguagem poética se torna, assim, o seu objeto, alterando também o costume de lê-la e declamá-la, o canto medieval se não se dissipa inteiramente, torna-se murmúrio, eco paradoxal da música perdida. Essa é uma mudança, um paradigma real, que tem um profundo e permanente efeito na literatura e no modo como é pensado, narrado ou declamado o «eu» e o escutar a si mesmo. Ainda, é uma mudança que autoriza a aproximação entre poesia e as outras formas de pensamento, como a filosofia e a psicologia.

A sublime ambição da obra Dante é estudada por Georges Didi-Huberman (2012), em A pintura encarnada, a partir do conto de Honoré de Balzac, A obra-prima ignorada. O tema é similar em ambas: uma imagem se desdobra e se desloca do seu conteúdo original. É algo como uma cena que diz respeito ao sujeito, embora lhe cause estranhamento. $\mathrm{O}$ ato de contemplar uma imagem em excesso, como o faz Dante Alighieri ou o pintor Frenhofer em seu jogo rumo à verdade é que, na modernidade, aquele que vê é também aquele que se torna objeto do olhar, e não mais puro olhar em direção ao objeto. O que se pode apreender, então, é que o lugar do fantasma na teoria da cultura é a cadeia incessante de significados gerada rumo ao vazio.

Em A Pintura Encarnada, de Didi-Huberman, a ideia da carne na pintura é o que permite que aquele que busca o desvelamento da obra de arte se instaure para fora da superfície da obra. Trata-se de um ato de desvio do olhar, operando uma ação de ida e volta da superfície ao que há de mais profundo; é assim que o olhar na modernidade se expande. Para ele (2012, p.41), «o quadro não é apenas um tópico, mas algo dinâmico e vivo, o diáfano pensado como uma biologia do visível» $\mathrm{O}$ corpo, a partir de um centro que se desvia para as margens e que se desvia das margens em direção a um centro também ilusório. Esse ato de deixar de ocultar a relação entre a imagem do corpo pictórico e a alegoria é o que torna a pintura dotada de carnatura, porém, é a frustração de alcançar esse limite encerrado na imagem pictórica que o ato de desvelamento do olhar denuncia como «aporia da projeção». 
A pintura encarnada trata do tema da encarnação da pintura. A obra é dividida em duas partes: a primeira se dedica a explorar a ideia de uma pintura que seja capaz de rumar para além da representação; na segunda, o autor se volta para o texto de Balzac para colocar em prática sua análise do que ele considera como exemplo para se pensar o destino, a origem e os mecanismos que constituem a estrutura, a carnatura da superfície pictórica. A imagem ativa o olhar que deve se desviar da própria imagem, ato necessário, pois o que está em curso é a ilusão da obra concluída. A questão primordial, neste caso, é estabelecer qual o limite que a obra pode alcançar? Questão que também parece central em Dante, já que sua musa, Beatriz é a sua pintura encarnada, para ele, é a ideia transformada em ato desvelador, caminho para a sublimação poética de algo que está para além dos limites da obra. Valores de desejo e prazer se consubstanciam na imagem de Beatriz que fala a Dante como o próprio Dante no Canto XXIII do Paraíso:

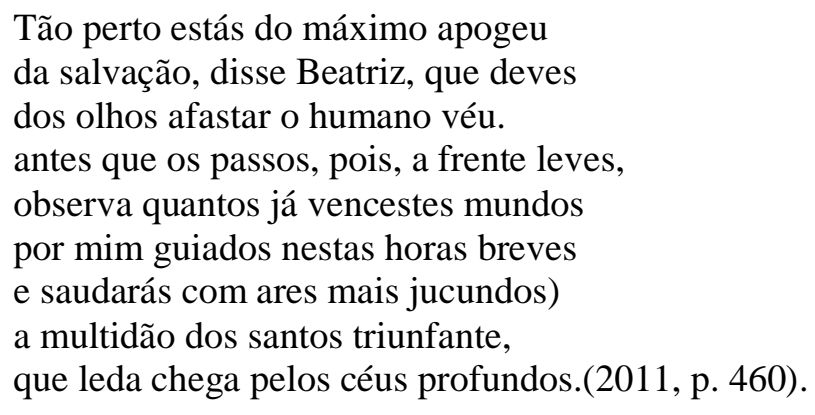

Tão perto estás do máximo apogeu da salvação, disse Beatriz, que deves dos olhos afastar o humano véu. antes que os passos, pois, a frente leves, observa quantos já vencestes mundos por mim guiados nestas horas breves e saudarás com ares mais jucundos) a multidão dos santos triunfante, que leda chega pelos céus profundos.(2011, p. 460).

Para que o olhar encontre o material vivo e dotado de energia na obra, o que é intangível precisa também se tornar carne, precisa se tornar parte de uma biologia mais profunda, por isso Dante fala por Beatriz e Balzac por Frenhofer. A carne da obra, quando desvelada pelo olhar desviante e oblíquo encontra outra relação entre a imagem do corpo, ou seja, de seu caráter pictórico e sua representação alegórica surge a carne da pintura que frustra o olhar.

\section{Considerações finais}

Em Dante, o ato de projetar a visão para a encarnação da obra é a tentativa de completar o percurso do ato de potência permeado por fissuras que escapam ao olhar. Nesse ponto, 
talvez a importância de Vida nova seja emblemática, pois nela se entrevê os dilemas do artista moderno, a saber, o abismo entre as limitações do ato criativo e a ilusão, o desejo, sempre necessário de tê-la superado em ato criativo.

A relação entre desejo e a acídia, por exemplo, é revista pelo poeta florentino em vários capítulos da Comédia, mas o que Dante atribui à acídia como forma de amor já está presente nas obras anteriores, o último soneto de Vida nova, por exemplo, não apenas dá o mote para o caminho da criação da Comédia, mas, além disso, contém os elementos que perfazem a essência da doutrina pneumática medieval. Neste último poema de juventude, por exemplo, o que se percebe é que, graças ao conhecimento da psicologia medieval, Dante promove uma forte autoescuta como metáfora do amor:
Além da esfera que mais larga gira
passa o suspiro que sobe do meu peito:
nova inteligência, a qual o Amor,
chorando, nele põe, para que suba.
Quando é chegado lá onde deseja,
vê uma dama, centro de honrarias
e virtudes tantas, que por seu esplendor
a olhá-la fica o peregrino espírito.
E vê-a tal, que o não percebo quando
o oiço; não sei que o faz falar
ao peito dolorido, tão subtil é.
Sou eu, enfim, que falo daquela formosíssima,
que bastante recordo Beatriz,
assim que bem o entendo, damas minhas (1993, p. 92).

Os trovadores da Idade Média não poderiam desenvolver como Dante o espaço da clausura como o lugar «Além da esfera que mais longe gira», dotando-o das tensões eróticas entre a clausura e o desejo elevados a um paroxismo impossível. Assim, o momento em que a poesia lírica trovadoresca, cuja marca central é a oralidade, se vê sobrepujada pela lírica moderna é também o momento em que se modifica a própria natureza da representação. É justamente esse o instante da introdução do elemento fantasmático, a fantasia como objeto de desejo, quando o poeta passa a prescindir da percepção sensível do objeto em nome de um ideal objetal, ou uma erótica textual, consciente e mental, mais hermenêutica que simbólica, separando de vez o sujeito do 
objeto. Tendo a forma musical do soneto como tema central, principalmente os sonetos de Dante Alighieri em Vida nova, para Giorgio Agamben,

é simplesmente impossível distinguir entre o médico e o filósofo. Tal entrelaçamento de motivos explicitamente médicos com temas que consideramos filosófico-literários é perceptível também nos poetas, cuja obra, conforme poderemos verificar, fica muitas vezes ininteligível sem um bom conhecimento de anatomia do olho, do coração e do cérebro, dos modelos circulatórios e da embriologia medievais, não só porque os poetas se referem diretamente às doutrinas fisiológicas do seu tempo, mas também porque frequentemente tal referência está costurada com uma intenção alegórica, que se exerce de maneira privilegiada sobre a anatomia e a fisiologia do corpo humano (2012, p. 139).

Demarcar o estabelecimento da nova concepção de lírica, o doce estilo novo ou a ética fantasmática, sem substância é o traço distintivo da poesia lírica de Dante Alighieri, é o modo como os poetas renascentistas exploram justamente essa tensão entre o espaço do amor e da perda, rastro de pensamento impossível para a ética medieval.

De que modo uma arte tão desinteressada pode acompanhar as mudanças do mundo medieval? Essa é uma das questões apresentadas por Giorgio Agamben e Georges DidiHuberman, dois pensadores contemporâneos que não apenas estabelecem os limites na dinâmica do mundo medieval que determinaram seu declínio, mas, sobretudo, estabelecem um momento fantasmático privilegiado para a construção do Ego a partir da dissolução do mundo medieval. Sabe-se que por meio da semiótica, do estético e do patético (pathos), tem-se acesso não ao pensamento em si, mas sim ao entrelaçamento, à estrutura da pele.

Peles são marcas, são escrituras que se conjugam no ato da vestidura como modo de encobrimento, pele como veste. Deve ser notado que o termo é utilizado no século dezesseis como investidura, e esse processo mantém relação com investidura mesmo hoje, tanto carnal quanto espiritual.

A linguagem de Dante se apresenta como estilhaços de signos que conduzem tanto à técnica quanto ao autoconhecimento; habilidade e êxtase se entrelaçam na superfície da linguagem, como uma sobreposição de imagens, de cores, de movimentos que pulsam estáticos e desenfreados numa sucessão de painéis. $O$ acaso dirige o poeta para a finalização, por certo ilusória, do arremate da obra. Mas, no caso específico da literatura, a técnica é utilizada como parte do entrecruzamento do cálculo, que deve ser impresso na imagem poética como redução entre as dimensões de plasticidade do signo. O objeto de 
perquirição na escrita é ato de encobrimento, mas deixa ao leitor a possibilidade de estabelecer um processo de colagem do jorro, ao mesmo tempo que o aliena da história do jorro, tornando-se, então, gesto reinventor do signo de arte.

É na esteira dessas reflexões que uma leitura de Dante pôde ser proposta. Uma leitura que, desde a Vida nova e a Comédia, buscou apreciar o proceso de configuração da voz poética do poeta toscano que, partindo de elementos, tradições e discussões literárias medievais, deles se deslinda e emerge com características modernas que particularizam a voz e a presença do poeta, assim como o propósito final da poesia. E é neste sentido que essa configuração debe ser entendida como um projeto estético e moral que está no centro da concepção poética de Dante Alighieri.

\section{Referências bibliográficas}

1. Agamben, G. (2012). Estâncias: a palavra e o fantasma na cultura ocidental. Tradução de Selvino José Assmann. Belo Horizonte: Editora da UFMG. (2013). O homem sem conteúdo. (Tradução, notas e posfácio de Cláudio Oliveira. 2a ed.); Belo Horizonte: Autêntica Editora.

2. Alighieri, Dante. (1993). Vida nova. Tradução dos originais italiano e latino por Carlos Eduardo Soveral. $3^{\text {a }}$ edição. Lisboa: Guimarães Editora. (2011). Divina comédia. (Tradução e notas de João Trentino Ziller. Apresentação de João Adolfo Hansen). Campinas: Editora da Unicamp.

3. Bloch, Howard. R. (1995). Misoginia medieval e a invenção do amor romântico ocidental. (Tradução de Cecília Moraes). Rio de Janeiro: Editora 34.

4. Bloom, Harold (2001). Gênio. (Tradução de Marco Costacurta). São Paulo: Editora Perspectiva.

5. De Balzac, H. (2012). A obra-prima ignorada. (Tradução de Teixeira Coelho). São Paulo: Iluminuras.

6. Didi-Huberman, G. (2012). A pintura encarnada: seguido de A obra-prima desconhecida, de Honoré de Balzac. (Tradução de Osvaldo Fontes Filho e Leila de Aguiar Costa). São Paulo: Escuta.

LINGÜÍSTICA Y LITERATURA 
7. Duby, G. (2001). Eva e os Padres: damas do século XII. (Tradução de Maria Lúcia Machado). São Paulo: Companhia das Letras.

8. Holiday, H. (1882/1884) Dante e Beatrice. l'incontro immaginario fra Dante e Beatrice (con il vestito bianco) accompagnata dall'amica Vanna (con il vestito rosso), sul Ponte Santa Trinità in Firenze. [Pintura] Walker Art Gallery, Liverpool. Disponível em https://upload.wikimedia.org/wikipedia/commons/f/f8/Dante_and_beatrice.jpg 9. Sterzi, E. (2008). Por que ler Dante. São Paulo: Globo. 